\title{
Editorial: Homage to Carlos Eduardo de Mattos Bicudo
}

\author{
Denise de Campos Bicudo ${ }^{1 *}$
}

${ }^{1}$ Laboratório de Ecologia Aquática, Departamento de Ecologia, Instituto de Botânica de São Paulo - IBt, Avenida Miguel Stéfano, 3687, Vila Água Funda, CEP 04301-902, São Paulo, SP, Brasil *e-mail: denisecbicudo@gmail.com

Cite as: Bicudo, D.C. Editorial: Homage to Carlos Eduardo de Mattos Bicudo. Acta Limnologica Brasiliensia, 2018, vol. 30, e200.

To talk about the professional trajectory of Prof. Carlos E. de M. Bicudo is, above all, a real pleasure and brings us great joy.

Carlos graduated in Natural History at the University of São Paulo in 1963. Even before graduating, he was already interested in aquatic microorganisms and discovered the world of microalgae. Newly graduated, he sought professionals in this field and held an internship with Prof. Samuel Murgel Branco who was a pioneer in Brazil and an expert on taxonomy of microalgae genera from continental waters. After a period, Prof. Samuel recommended Carlos to improve his taxonomic knowledge on algae abroad. On the advice of Prof. Ayrton B. Joly, he contacted Prof. Dr. G. W. Prescott and joined his team in a collection trip to Patagonia (Argentina). Invited by Prof. Prescott, he went to Michigan State University to hold a master's degree in Botany, graduating in 1965. During his master's studies, he worked with desmids, although he always sought an eclectic formation, aware of his role in the training of phycologists in Brazil.

Back in Brazil, he resumed his activities at "Instituto de Botânica" and held a doctorate in Biological Sciences (Botany) at the University of São Paulo in 1973, working in the revision of a desmid genus under the guidance of Prof. A. B. Joly.

In 1975, Prof. Prescott invited him to work in the "Synopsis of North American Desmids" for two years, which resulted in the publication of five volumes, three of which as a contributing author (Prescott et al., 1981, 1982; Croasdale et al., 1983). During this period, he further extended his interaction with international experts from different fields.

Since then, he has been working intensively in research and education, mainly at the postgraduate level and in the training of human resources. To date, he has advised 45 masters and 50 doctors and has published 190 articles in journals of different research areas of Phycology and Limnology (e.g. Lopes et al., 2005; Bicudo et al., 2007; Crossetti \& Bicudo, 2008; Fonseca \& Bicudo, 2010; Barbosa et al., 2013; Marquardt et al., 2017; Crossetti et al., 2018; Ramos et al., 2018). He organized and published 36 books and 35 book chapters (e.g. Parra \& Bicudo, 1996; Tundisi et al., 1995; Bicudo \& Bueno, 2013; Bicudo et al., 2017). He has always been concerned with the elaboration of books in Portuguese to facilitate the introduction of young researchers and environmental managers, among others, to the study and use of algae for different purposes. These books had quick and high visibility, reaching a wide audience and hundreds of citations. His most feature publications are the volumes on algae genera from Brazilian continental waters, which has four revised and expanded editions, the last published in 2017 (Bicudo \& Menezes, 2017); four translations to Portuguese of the International Code of Nomenclature for Algae, Fungi and Plants, published in 2003, 2006, 2012 and 2018 (e.g. Bicudo et al., 2018b); the book Sampling in Limnology (Bicudo \& Bicudo, 2007) resulting from a multidisciplinary workshop; a book on a Biological Reserve with a multidisciplinary approach (Bicudo et al., 2002); as well as large algae inventories, such as 
the Phycological Flora of São Paulo state with seven published volumes (e.g. Picelli-Vicentim et al., 2004; Bicudo et al., 2015, 2018a; Bicudo \& Samanez, 2016); and 100 years of the Guarapiranga Reservoir, lessons and challenges (Bicudo \& Bicudo, 2017), among others.

Always committed to teaching, research and actions for the scientific development of Brazil and Latin America, Carlos is recognized by the national and international audience as evidenced by the distinctions he received throughout his professional life. He is an Honorary Professor of the National University of Trujillo and the National University of the Peruvian Amazon, both from Peru. He is emeritus member of the Brazilian Society of Botany and the Brazilian Association of Limnology and a member of the Brazilian Academy of Science. In 2012, he received the "Graziela Maciel Barroso" Botany Merit Medal for his relevant contribution to Botany development in Brazil. Also in that year, he received a tribute from "Instituto de Botânica" for his contribution in developing the institution. In 2017, he received a tribute from the Brazilian Association of Limnology for his participation in the consolidation of the Brazilian Limnology, and in the same year, he received a tribute from the Latin American Phycological Society in recognition of his contribution to the development of Latin American Phycology.

His dedication to research and education goes far beyond what the numbers might indicate. Prof. Carlos is a living example of a long trajectory built with love, dedication, sharing of knowledge, integrity, and hard work. All his present and past students and the people who just shared experience with him will always be profoundly grateful for his open and welcoming mind, his lessons and his joy. Carlos, affectionately called "Ori" by his scientific family, represents an indelible legacy in our lives.

This section is a tribute to the 80th anniversary of Carlos E. de M. Bicudo, which occurred on 28 Nov 2017, and gathers together 15 articles written by his students, ex-students, and researchers who he influenced. These articles exemplify his relevant contribution to the advancement and diversification of research on continental algae in Brazil.

\section{References}

BARBOSA, L.G., BARBOSA, F.A.R., ARAUJO, G.J.M. and BICUDO, C.E.M. The dominance of desmids in tropical monomictic lakes (SE Brazil). Limnetica, 2013, 32, 71-86.

BICUDO, C.E.M. and BICUDO, D.C., eds. Amostragem em limnologia. 2. ed. São Carlos: RiMa, 2007, 351 p. vol. 1.

BICUDO, C.E.M. and BICUDO, D.C., eds. 100 anos da represa Guarapiranga: liçóes e desfaios. 1. ed. Curitiba: CRV, 2017, 506 p. vol. 1.

BICUDO, C.E.M. and BUENO, N.C. Characeae biomass: is the subject exhausted? In: M.D. MATOVIC, ed. Biomass now: sustainable growth and use. 1st ed. Rijeka: InTech, 2013, pp. 523-540. http://dx.doi.org/10.5772/54685.

BICUDO, C.E.M. and MENEZES, M., eds. Gêneros de algas de águas continentais do Brasil: chave para identificação e descriçóes. 3. ed. São Carlos: RiMa, 2017, 572 p.

BICUDO, C.E.M. and SAMANEZ, I.M. Flora ficológica do Estado de São Paulo. Parte 5: Zygnemaphyceae. 1. ed. Sáo Carlos: RiMa, 2016, 76 p. vol. 4.

BICUDO, C.E.M., FAUSTINO, S.M.M. and GODINHO, L.R. Zygnemaphyceae. Parte 4. São Carlos: RiMa, 2018a, 329 p. vol. 4.

BICUDO, C.E.M., PRADO, J. and HIRAI, R., eds. Código Internacional de Nomenclatura para algas, fungos e plantas: código de Melbourne. São Carlos: RiMa, 2018b, 254 p.

BICUDO, C.E.M., SCHETTY, S.P. and PINTO, L.S.C. Flora ficológica do Estado de São Paulo. Parte 2. Zygnemaphyceae. 1. ed. São Carlos: RiMa, 2015, 148 p. vol. 4.

BICUDO, C.E.M., TUNDISI, J.G. and SCHEUENSTUHL, M. Waters of Brazil: strategic analysis. 1st ed. Basel: Springer, 2017, 191 p. vol. 1. http://dx.doi.org/10.1007/978-3-319-41372-3.

BICUDO, D.C., FONSECA, B.M., BINI, L.M., CROSSETTI, L.O., BICUDO, C.E.M. and ARAÚJO-JESUS, T. Undesirable side-effects of water hyacinth control in a shallow tropical reservoir. Freshwater Biology, 2007, 52(6), 1120-1133. http://dx.doi.org/10.1111/j.1365-2427.2007.01738.x.

BICUDO, D.C., FORTI, M.C. and BICUDO, C.E.M., eds. Parque Estadual das Fontes do Ipiranga (PEFI): unidade de conservação que resiste à urbanização de São Paulo. 1. ed. Sao Paulo: Secretaria do Meio Ambiente do Estado de São Paulo, 2002, 351 p.

CROASDALE, H., BICUDO, C.E.M. and PRESCOTT, G.W. A synopsis of the North American desmids. Lincoln: The University of Nebraska Press, 1983, 117 p. vol. 5. 
CROSSETTI, L.O. and BICUDO, C.E.M. Phytoplankton as a monitoring tool in a tropical urban shallow reservoir (Garças Pond): the assemblage index application. Hydrobiologia, 2008, 610, 161-173.

CROSSETTI, L.O., BICUDO, D.C., BINI, L.M., DALA-CORTE, R.B., FERRAGUT, C. and BICUDO, C.E.M. Phytoplankton interactions and invasion by Ceratium furcoides are influenced by extreme drought and water-hyacinth removal in a shallow tropical reservoir. Hydrobiologia, 2018. In press.

FONSECA, B.M. and BICUDO, C.E.M. How important can the presence/absence of macrophytes be in determining phytoplankton strategies in two tropical shallow reservoirs with different trophic status? Journal of Plankton Research, 2010, 32(1), 31-46. http://dx.doi.org/10.1093/plankt/fbp107.

LOPES, M.R.M., BICUDO, C.E.M. and FERRAGUT, C. Short term spatial and temporal variation of phytoplankton in a shallow tropical oligotrophic reservoir, southeast Brazil. Hydrobiologia, 2005, 542(1), 235247. http://dx.doi.org/10.1007/s10750-004-8332-z.

MARQUARDT, G.C., BLANCO, S. and BICUDO, C.E.M. Distance decay as a descriptor of the diatom compositional variation in tropical reservoirs. Marine \& Freshwater Research, 2017, 69(1), 105-113. http:// dx.doi.org/10.1071/MF17003.

PARRA, O.O. and BICUDO, C.E.M. Introducción a la biología y sistematica de las algas de aguas continentales. 1st ed. Concepción: Ediciones Universidad de Concepción, 1996, 268 p. vol. 1.

PICELLI-VICENTIM, M.M., BICUDO, C.E.M. and BUENO, N.C. Charophyceae. São Carlos: RiMa, 2004. vol. 5.

PRESCOTT, G.W., BICUDO, C.E.M. and VINYARD, W.C. A synopsis of the North American desmids. Lincoln: The University of Nebraska Press, 1982, 700 p. vol. 4.

PRESCOTT, G.W., CROASDALE, H.T., VINYARD, W.C. and BICUDO, C.E.M. A synopsis of the North American desmids. Lincoln: The University of Nebraska Press, 1981, 720 p. vol. 3.

RAMOS, G.J.P., BICUDO, C.E.M. and MOURA, C.W.N. Some new, rare and interesting desmids from bromeliad phytotelmata in Brazil. Phytotaxa, 2018, 346(1), 59-77. http://dx.doi.org/10.11646/phytotaxa.346.1.3.

TUNDISI, J.G., BICUDO, C.E.M. and MATSUMURA-TUNDISI, T. Limnology in Brazil. Rio de Janeiro: Academia Brasileira de Ciências e Sociedade Brasileira de Limnologia, 1995, 376 p. 